\title{
MEDIA E-LEARNING BERBASIS CMS JOOMLA: PELENGKAP PEMBELAJARAN FISIKA SMA
}

\section{E-Learning Media Based CMS Joomla: Physics Senior High School Learning Supplement}

\author{
Fauzi Bakri, Farah Fajriani, Dewi Muliyati \\ Program Studi Pendidikan Fisika, Universitas Negeri Jakarta \\ Jl. Rawamangun Muka No.1, Jakarta 13220 \\ Email: fauzi-bakri@unj.ac.id
}

Diterima: 10 April 2017, direvisi:

28 April 2017, disetujui:

5 Mei 2017.
ABSTRACT: The 21st century learning can be done without limitation of space and time with e-learning media. The problem is how Joomla Content Management System (CMS) based e-learning media devices for Physics in senior high school is developed. This study aims to produce a CMS Joomla-based e-learning device for physics in senior high school. The method used in this research is research and development method of Dick and Carey model. The e-learning device is material exposure in multiple-representation. Material is enriched with learning videos, exercise questions, learning evaluation tools, and discussion forums to facilitate interaction between students and teachers. Students learn independently, without limited space and time. This research uses Likert scale instrument 1-5 for formative evaluation of e-learning media device. For data analysis, this research uses qualitative data processing techniques. The result of the product assessment with the Likert instrument is expressed in the scale value of 100 . The result of the material feasibility test is 86,33 , media is 86.3 , study eligibility is 92,14 , field trial for physics teacher is 91,78 , and field trial with questionnaire is 85.44 . The result of e-learning media usage trial as a complement to learning indicates a value of 0.335 . The result of development research shows that Joomla CMS based e-learning media is feasible to be used in senior high school physics learning with excellent quality. In addition, students claim to gain significant additional knowledge after doing the learning independently through this e-learning media. In conclusion, CMS Joomla based e-learning media device is feasible and can be used as a physics learning model in senior high school. The recommendation is that teachers and/or students in senior high school use CMS Joomla based learming device for physics.

Key words: E-learning media, Joomla CMS, physics learning

ABSTRAK: Pembelajaran abad 21 bisa dilakukan tanpa batasan ruang dan waktu dengan media e-learning. Masalahnya adalah bagaimana pengembangan perangkat media e-learning berbasis Content Management System (CMS) Joomla untuk pembelajaran Fisika di SMA. Penelitian ini bertujuan untuk menghasilkan perangkat e-learning berbasis CMS Joomla untuk pembelajaran fisika di SMA. Metode yang digunakan pada penelitian ini adalah metode penelitian dan pengembangan model Dick and Carey. Perangkat e-learning yang dihasilkan adalah paparan materi secara multi representasi. Materi diperkaya video pembelajaran, latihan soal, perangkat 
evaluasi pembelajaran, serta forum diskusi untuk memudahkan interaksi antara peserta didik dan guru. Peserta didik belajar secara mandiri, tanpa terbatas ruang dan waktu. Penelitian ini menggunakan instrumen skala Likert 1-5 untuk evaluasi formatif perangkat media e-learning. Analisis data dalam penelitian ini menggunakan teknik pengolahan data kualitatif. Hasil penilaian produk dengan instrumen berskala Likert dinyatakan dalam nilai skala 100. Hasil uji kelayakan materi mendapat nilai 86,33, kelayakan media 86,3, kelayakan pembelajaran 92,14, uji coba lapangan untuk guru Fisika 91,78, dan uji coba lapangan dengan kuisioner 85,44. Hasil uji coba penggunaan media elearning sebagai pelengkap pembelajaran memberikan nilai gain sebesar 0,335 . Hasil penelitian pengembangan ini menunjukkan bahwa media e-learning berbasis CMS Joomla layak digunakan dalam pembelajaran Fisika SMA dengan kualitas sangat baik. Selain itu, peserta didik menyatakan mendapatkan tambahan pengetahuan cukup signifikan setelah melakukan pembelajaran secara mandiri melalui media elearning ini. Kesimpulannya media e-learning yang dikembangkan menggunakan CMS Joomla dinyatakan layak dan dapat digunakan sebagai model pembelajaran Fisika di SMA. Sarannya adalah agar pendidik dan/atau peserta didik menggunakan atau memanfaatkan media e-learning berbasis CMS Joomla dalam pembelajaran Fisika di SMA.

Kata Kunci: media e-learning, CMS Joomla, pembelajaran Fisika

\section{PENDAHULUAN}

Pembelajaran dalam abad 21 memiliki banyak perbedaan dibandingkan pembelajaran dalam abad 20. Tren abad 21 ditandai dengan berkembangnya Teknologi Informasi dan Komunikasi (TIK) serta sistem otomatisasi yang sangat pesat. Banyak pekerjaan rutin dan berulang-ulang mulai digantikan oleh mesin, baik mesin produksi maupun komputer (Wijaya Sudjimat, \& Nyoto, 2016). Dalam paradigma lama pembelajaran, peserta didik ditempatkan sebagai individu yang belum dewasa, individu yang pasif, objek dalam proses pembelajaran, dan juga menempatkan guru sebagai pusat kegiatan belajar. Paradigma pembelajaran ini tidak lagi memadai untuk menyiapkan Sumber Daya Manusia (SDM) abad 21 sebagai warga masyarakat global (Haryono, 2017).

Pemanfaatan TIK dalam sistem pembelajaran telah mengubah sistem pembelajaran pola konvensional atau pola tradisional menjadi pola modern. Salah satu bentuknya adalah media komputer yang menghasilkan pembelajaran elektronik. Lebih dari itu, media komputer yang dilengkapi internet bahkan dapat menghasilkan sistem pembelajaran digital atau pembelajaran berbasis TIK secara online (e-learning).

Pada model pembelajaran yang memanfaatkan media berbasis TIK, peserta didik dapat memilih materi pembelajaran berdasarkan minatnya sendiri. Proses pembelajaran menjadi menyenangkan, tidak membosankan, penuh motivasi, semangat, menarik perhatian dan penuh kesadaran. Penggunaan TIK dalam pembelajaran memberikan manfaat, baik bagi pendidik, peserta didik maupun masyarakat. Bagi pendidik, penggunaan TIK akan meningkatkan efektivitas dan efisiensi pembelajarannya. Bagi peserta didik, penggunaan berbagai teknologi akan memberikan kesempatan belajar yang lebih berkualitas (Husamah, 2014: 1-2).

E-learning didefinisikan sebagai proses pembelajaran tanpa menggunakan bahan ajar 
cetak kertas. E-learning adalah penggunaan TIK untuk menyampaikan materi dalam kegiatan pembelajaran. Kemajuan dan perkembangan TIK telah memunculkan elearning sebagai model pembelajaran modern. Keuntungan besar e-learning mencakup interaksi yang membebaskan peserta didik dan pendidik dari keterbatasan waktu dan ruang. Interaksi membentuk model jaringan pembelajaran yang dilakukan secara tidak sinkronous maupun secara sinkronous (Goyal, 2012).

Dalam studi empiris dari tahun 1996 dan 2008 disimpulkan bahwa peserta didik yang menggunakan e-learning lebih baik daripada peserta didik yang tidak menggunakan elearning. Selain itu, peserta didik yang berprestasi terbaik adalah mereka yang mendapat pembelajaran campuran. Untuk memaksimalkan potensi ini, implementasi $e$ learning harus berusaha untuk memenuhi kebutuhan dan keprihatinan semua kelompok pemangku kepentingan sebanyak mungkin (Jethro, Grace \& Thomas, 2012).

Manfaat desain program e-learning adalah kemudahannya sehingga bisa menggunakan berbagai sumber belajar. Desain pembelajaran yang mapan dan jelas serta berorientasi pada tujuan diperlukan untuk membuat e-learning lebih fokus, efektif, dan efisien (Srihartini, 2014). E-learning dapat dipandang sebagai perangkat pembelajaran dengan bantuan komputer. Proses instruksional dalam e-learning berpusat pada peserta didik dan bersifat kolaboratif. Elearning terdiri dari semua bentuk pembelajaran dan pengajaran yang didukung secara elektronik (Jethro, Grace \& Thomas, 2012). Oleh karena itu, e-learning merupakan pembelajaran yang memanfaatkan dan mengintegrasikan TIK.

Peserta didik memiliki kebutuhan untuk memahami dan menguasai suatu materi pelajaran yang diterima dari pendidik. Peserta didik dapat memahami suatu pelajaran yang disajikan oleh pendidik dengan menggunakan lebih dari satu metode dan media pembelajaran. Oleh karena itu, pendidik harus kreatif dan inovatif untuk mengembangkan dan menggunakan berbagai media pembelajaran yang membuat peserta didik dapat memenuhi kebutuhannya dalam memahami suatu materi pembelajaran.

Hasil penelitian tentang "Analisis Konsepsi Peserta Didik Pada Konsep Kinematika Gerak Lurus" menggambarkan bahwa peserta didik lebih banyak memiliki konsepsi yang tidak benar ketika menganalisis suatu kasus, khususnya tentang materi kinematika gerak lurus. Salah satu faktor penyebab rendahnya konsepsi peserta didik adalah pengalaman sehari-hari (Pujianto, Nurjanah \& Darmadi, 2013). Oleh karena itu, pembelajaran harus kontekstual sehingga dapat memberi pengalaman yang bermakna.

Mata pelajaran Fisika merupakan salah satu ilmu dasar yang memegang peranan penting dalam perkembangan ilmu pengetahuan dan teknologi (Sari, Bektiarso \& Yushardi, 2012). Fisika sebagai salah satu cabang ilmu pengetahuan (sains) terdiri dari beberapa konsep dasar tentang berbagai fenomena yang terjadi dalam kehidupan sehari-hari. Hal ini menyebabkan diperlukannya aktivitas-aktivitas dan pola pikir yang cermat oleh guru dan peserta didik dalam proses pembelajaran Fisika di sekolah (Kurniawan, Bektiarso \& Subiki, 2012).

Sekarang ini, sebagian besar lembaga pendidikan (universitas, institut, akademi, dan sekolah) menggunakan beberapa alat $e$ learning sebagai bagian integral dari sistem pembelajaran yang mereka kembangkan. Pengembangan e-learning ini dimaksudkan untuk meningkatkan kualitas sistem pembelajaran tradisional yang berbasis kelas atau menggunakan pendekatan alternatif untuk lingkungan belajar virtual. Media ini dapat dikembangkan berdasarkan pada pengelolaan pembelajaran atau pengelolaan konten pembelajaran (Ninoriya, Chawan \& Meshram, 2011).

Pemanfaatan media pembelajaran Fisika berbasis web dinilai dapat mengatasi keterbatasan pada proses pembelajaran dan dapat memfasilitasi peserta didik dalam memahami materi Fisika (Bakri \& Muliyati, 2017). Mengembangkan e-learning berbasis web dapat menggunakan Content Management System (CMS). Dengan aplikasi tersebut, web developer tidak harus menguasai pemrograman web, namun cukup 
meng-install dan mengganti isi sesuai yang dikehendaki (Daru, 2013). Artinya penggunaan CMS dalam mengembangkan media e-learning dapat dilakukan secara mudah tanpa harus menguasai sistem pemrograman.

Sistem Manajemen Konten (Content Management System atau CMS) didefinisikan sebagai kombinasi dari tiga konsep yang berbeda, yaitu: konten, proses, dan teknologi yang dalam hal ini perangkat lunak. Konten adalah teks, grafik, animasi, audio, video, dan semua media lainnya yang menjadi dasar sistem. Suatu proses didefinisikan sebagai kumpulan kegiatan yang mengambil satu atau lebih input dan melakukan tindakan untuk menghasilkan keluaran. Sebuah proses mengacu pada cara yang terintegrasi ke dalam sistem agar pengguna dapat melakukan tugas pembelajaran. Teknologi atau perangkat lunak (software) diperlukan untuk melakukan proses dalam mengendalikan konten pembelajaran melalui internet (Altun, Gulbahar, \& Madran, 2008).

CMS bisa didefinisikan sebagai software yang mampu mengelola isi atau content dari sebuah website seperti melakukan publikasi, edit ataupun menghapus sebuah konten. Kategori konten ini bisa berupa tulisan, gambar, file ataupun yang lainnya (Gunadi \& Lirva, 2007). Salah satu CMS Open Source adalah CMS Joomla. Kelebihan CMS ini terletak pada kemudahan instalasi dan pengelolaannya. Oleh karena itu, penggunaan CMS Joomla dalam mengembangkan media e-learning Fisika sangat mudah dan sesuai kebutuhan pembelajaran sains. Media dapat disajikan secara multi representasi sains dan kontekstual.

Perangkat lunak CMS Joomla dapat membangun situs web dan sistem pengelolaan komunitas pembelajaran yang hebat. Banyak aspek, termasuk kemudahan penggunaan dan perluasan, membuat CMS Joomla menjadi perangkat lunak situs web terpopuler. CMS Joomla adalah solusi open source yang tersedia secara gratis untuk semua orang. Pendidik dapat mengembangkan keterampilan dan kemampuan siswa melalui portal elektronik dan meningkatkan kualitas pembelajaran peserta didik (Hussein \& Afaf, 2014). Kelas yang menggunakan modul berbasis elearning dengan perangkat lunak CMS Joomla mendapat hasil yang baik dan media yang digunakan dapat membantu peserta didik belajar mandiri (Wibawa, 2017).

Berdasarkan uraian di atas, rumusan masalah penelitian ini adalah bagaimana pengembangan perangkat media e-learning berbasis CMS Joomla untuk pembelajaran Fisika SMA kelas X semester 1. Adapun tujuan penelitian ini adalah untuk menghasilkan perangkat media e-learning berbasis CMS Joomla untuk pembelajaran Fisika di SMA. Akhirnya perangkat e-learning berbasis CMS Joomla hasil penelitian ini diharapkan dapat bermanfaat untuk mempermudah peserta didik dalam belajar Fisika di SMA yang tidak berbatas ruang dan waktu.

\section{METODA}

Penelitian ini dilakukan pada bulan Desember 2016 sampai Juni 2017 di laboratorium digital pendidikan Fisika Universitas Negeri Jakarta (UNJ). Uji kelayakan dilakukan oleh ahli materi, ahli media, serta ahli pembelajaran yang merupakan Dosen UNJ. Ujicoba lapangan dilakukan di SMA Negeri 30 Jakarta dengan sampel peserta didik kelas $X$ sejumlah 15 orang pada tahun pelajaran 2017/2018. Pengumpulan data menggunakan instrumen angket dengan skala Likert 1-5. Analisis data dalam peneitian ini menggunakan teknik pengolahan data kualitatif. Hasil penilaian produk dengan instrumen berskala Likert dinyatakan dalam nilai skala 100.

Metode penelitian yang digunakan adalah metode penelitian dan pengembangan (Research and Development). Metode tersebut paling tepat karena metode ini digunakan untuk pengembangan produk baru atau menyempurnakan produk yang sudah 
ada. Adapun model pengembangan instruksional yang digunakan dalam melakukan penelitian pengembangan ini adalah model pengembangan instruksional Dick and Carey (Dick \& Carey, 2015).

Model pengembangan sistem instruksional oleh Walter Dick dan Lou Carey merupakan salah satu model yang paling banyak digunakan dalam penelitian dan pengembangan pembelajaran. Model pengembangan instruksional Dick and Carey memiliki beberapa langkah perancangan yang harus dilakukan dalam proses pengembangan dan perencanaan tersebut. Penelitian ini hanya mengikuti sembilan tahapan mulai dari awal pengembangan sampai pada evaluasi formatif dengan menggunakan uji kelayakan produk oleh ahli media. Adapun langkah-langkahnya adalah: (1) Identify Instructional Goals, melakukan identifikasi kompetensi inti yang harus dikuasai peserta didik dalam mata pelajaran Fisika di SMA; (2) Conduct Instructional Analysis, melakukan analisis kompetensi dasar yang harus dimiliki peserta didik dalam mata pelajaran Fisika di SMA; (3) Analyze Learners and Contexts, mengidentifikasi entry behaviors dan learner characteristics peserta didik dalam mata pelajaran Fisika SMA; (4) Write Performance Objectives, menuliskan tujuan pembelajaran yang akan ditampilkan dalam media e-learning untuk setiap kompetensi yang sudah dirumuskan; (5) Develop Assessments Instruments, merancang bentuk penilaian dan instrumen penilaian yang akan digunakan untuk mengukur capaian kompetensi yang dimiliki peserta didik setelah mengikuti pembelajaran dengan media e-learning; (6) Develop Instructional Strategy, mengembangkan strategi pembelajaran yang dikembangkan secara kontekstual dan multi representasi dalam sistem e-learning mata pelajaran Fisika SMA, dan disajikan; (7) Develop and Select Instructional Materials, melakukan pemilihan dan pengembangan materi pembelajaran dengan memilih representasi video, gambar, animasi, data, grafik, persamaan Matematika yang relevan dengan materi pembelajaran Fisika SMA yang kontekstual serta dengan mengembangkan bahan belajar yang representatif pada perangkat e-learning berbasis CMS Joomla; (8) Design and Conduct Formative Evaluation of Instruction, merancang evaluasi formatif untuk menyempurnakan media e-learning untuk pelengkap pembelajaran Fisika SMA; dan (9) Revise instructional, melakukan revisi dalam penyempurnaan media e-learning mata pelajaran Fisika SMA berdasarkan hasil evaluasi formatif. Revisi dilakukan terhadap semua aspek yang memiliki kelemahan, baik dari strategi e-learning maupun perangkat representasi pendukungnya.

\section{HASIL DAN PEMBAHASAN}

\section{Komponen Perangkat Media E-Learning}

Penelitian ini menghasilkan produk berupa media belajar e-learning berbasis website dengan menggunakan CMS Joomla. Perangkat media e-learning dengan menggunakan CMS Joomla untuk pembelajaran Fisika SMA dapat diakses dengan menggunakan alamat: http:// sma10a.fisika-unj.ac.id.

Homepage merupakan bagian depan web e-learning yang mengatur penggunaan perangkat melalui proses masuk (login). Halaman sebelum login berisi kolom login pengguna (username) dan sandi masuk (password), menu petunjuk, tempat registrasi, serta informasi yang sedang menggunakan media (who's online) seperti pada Gambar 1 berikut.

\section{Hasil Evaluasi Formatif}

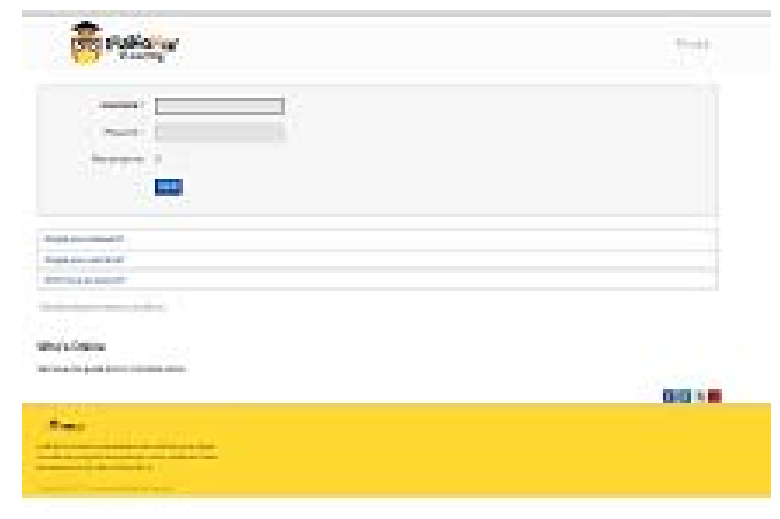

Gambar 1: Tampilan Halaman Sebelum login 


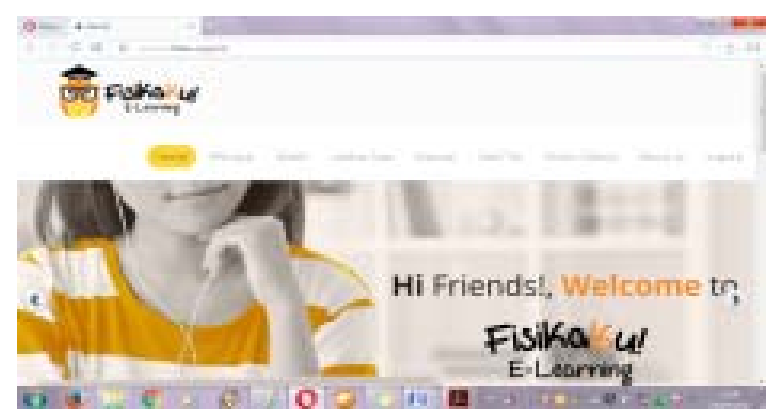

Gambar 2, Tampilan homepage Sesudah login Bagian Atas

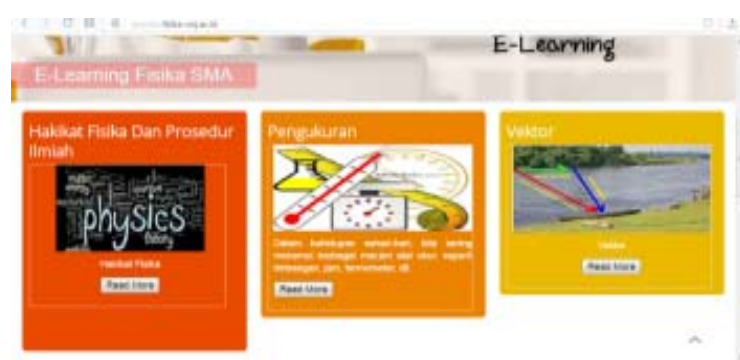

Gambar 3, Tampilan homepage Sesudah login Bagian Tengah

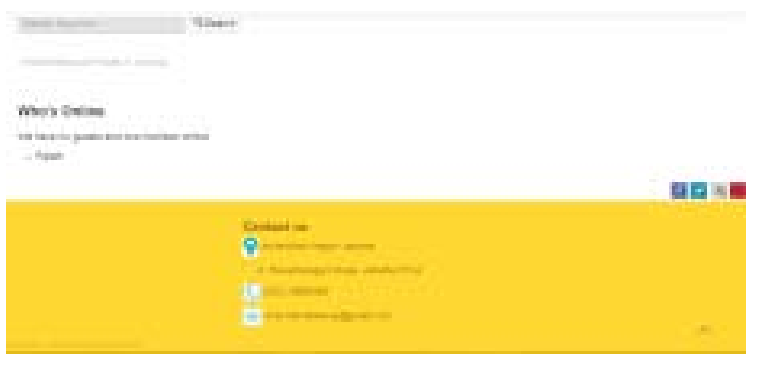

Gambar 4, Tampilan homepage Sesudah login Bagian Bawah

\section{Halaman Petunjuk}

Halaman petunjuk berisi petunjuk untuk melakukan registrasi, dan penjelasan penggunaan website FisikaKu E-learning. Menu petunjuk ini dapat diakses saat berada di halaman sebelum login maupun sesudah login.

\section{Halaman Materi}

Halaman materi berisi pilihan materi pelajaran pada SMA kelas X semester 1 . Pengguna dapat memilih materi yang ingin dipelajari. Setelah pengguna memilih salah satu materi, seperti materi Kinematika Gerak Lurus, maka akan tampil daftar sub materi pelajaran.
Di dalam materi, terdapat beberapa video. Video dapat dilihat setelah meng-klik gambar yang menandakan bahwa terdapat video di dalam gambar tersebut. Video menggunakan component All Video Share sebagai salah satu extensions pada CMS Joomla ini sehingga dapat muncul seperti pada Gambar 5 berikut ini.

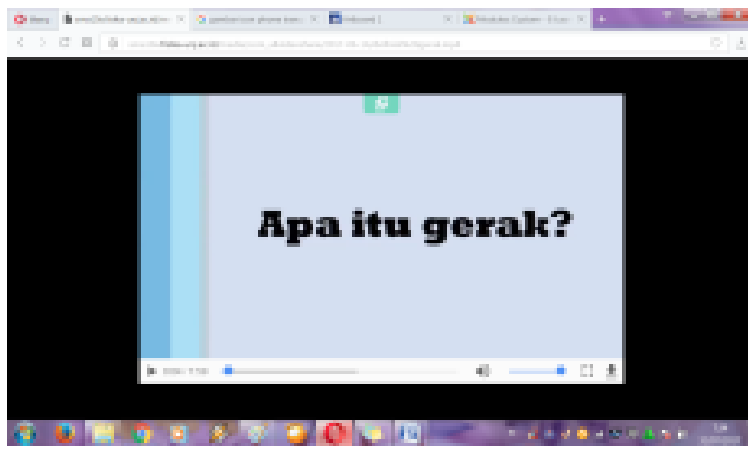

Gambar 5, Tampilan Video Saat Sudah Di-play Halaman Latihan Soal

Halaman latihan soal berisi pilihan materi untuk latihan soal. Latihan soal dibuat dengan menggunakan component ARI Quiz Lite. Pengguna dapat memilih latihan soal pada materi yang ingin dikerjakan. Setelah pengguna memilih salah satu materi untuk latihan soal, seperti materi Kinematika Gerak Lurus, akan tampil latihan soal tentang Kinematika Gerak Lurus dalam bentuk soal free text. Setelah pengguna (peserta didik) selesai mengerjakan latihan soal, akan muncul rincian hasil/nilai dari latihan soal yang telah peserta didik kerjakan. Guru dapat melihat hasil dari soal-soal yang dikerjakan peserta didik secara detail pada back end.

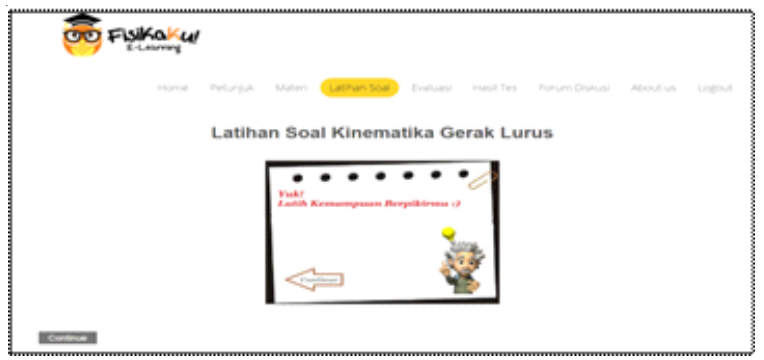

Gambar 6, Tampilan Awal Halaman Latihan Soal Kinematika Gerak Lurus

\section{Halaman Evaluasi}

Halaman evaluasi/tes berisi pilihan materi untuk evaluasi/tes. Evaluasi dibuat dengan menggunakan component ARI Quiz Lite. 
Pengguna dapat memilih evaluasi/tes pada materi yang ingin dikerjakan. Setelah pengguna memilih salah satu materi, seperti materi Kinematika Gerak Lurus, akan tampil soal-soal evaluasi tentang Kinematika Gerak Lurus dalam bentuk soal pilihan ganda. Kemudian, setelah pengguna (peserta didik) selesai mengerjakan evaluasi/tes, maka akan muncul rincian hasil/nilai dari evaluasi/tes yang telah peserta didik kerjakan.

\section{Halaman Hasil Tes}

Halaman hasil tes berisi seluruh hasil tes yang telah dikerjakan oleh pengguna (peserta didik), baik latihan soal maupun evaluasi seperti pada Gambar 7 berikut ini.

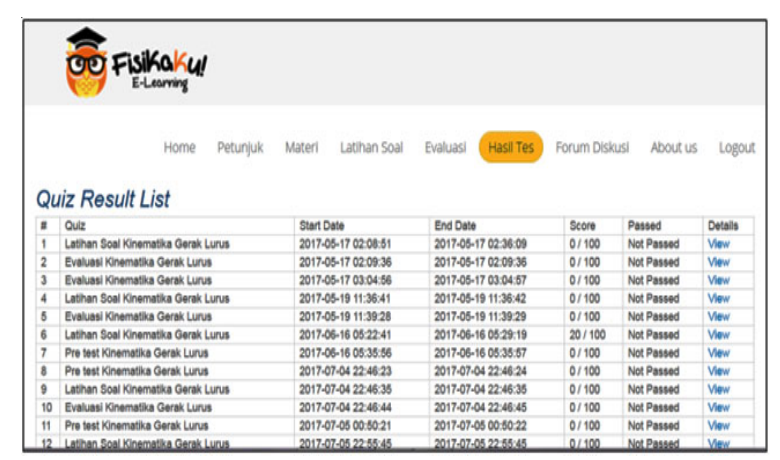

Gambar 7 Tampilan Halaman Hasil Tes

\section{Halaman Forum Diskusi}

Pada halaman 'forum diskusi', admin/guru dan pengguna (peserta didik) dapat berinteraksi atau berdiskusi dengan mengisi kolom comment yang telah tersedia. Forum diskusi ini menggunakan component comments yang merupakan extensions dari e-learning berbasis CMS Joomla ini. Guru/admin dapat mengelola forum diskusi dan memantau diskusi pada back end. Misalnya, jika ada komentar yang tidak sesuai, guru/admin dapat menghapus komentar tersebut pada back end seperti pada Gambar 8 berikut ini.

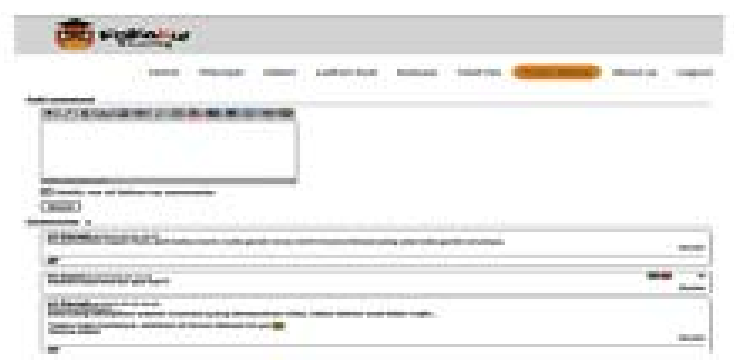

Gambar 8, Tampilan Halaman Forum Diskusi Pada front end

\section{Halaman About Us}

Halaman 'about us' berisi informasi tentang e-learning dan yang mengembangkan FisikaKu E-learning menggunakan CMS Joomla seperti Gambar 9 berikut ini.

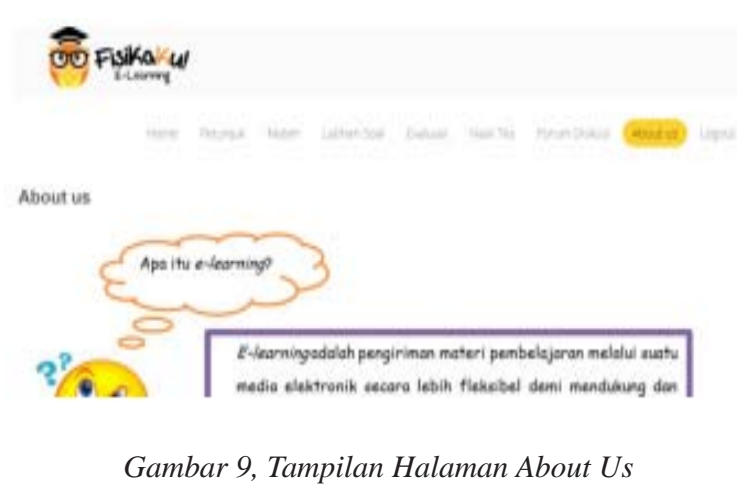

\section{Halaman Logout}

Agar akun pengguna aman, setelah selesai menggunakan web FisikaKu Elearning ini, pengguna dapat keluar dengan mengklik tombol 'logout' pada menu logout.

Hasil evaluasi formatif terhadap media elearning yang dihasilkan menunjukkan informasi dan data bahwa media mendapat interpretasi dinilai sangat baik untuk digunakan sebagai media e-learning. Evaluasi formatif dilakukan dalam bentuk uji kelayakan. Pengembangan model e-learning berbasis CMS Joomla diuji kelayakannya oleh ahli materi, ahli media, ahli pembelajaran, dan uji lapangan kepada peserta didik dan guru Fisika SMA Negeri 30 Jakarta.

Uji validasi materi dilakukan oleh ahli materi yaitu dosen program studi Fisika Universitas Negeri Jakarta. E-learning diuji kelayakannya menggunakan angket dengan 16 pertanyaan dari 3 aspek, yaitu: (1) desain materi e-learning; (2) paparan materi; dan (3) bahasa. Skala penilaian menggunakan skala Likert 1-5. Proses validasi materi dilakukan sebanyak tiga kali. Ada beberapa perbaikan paparan materi sesuai hasil masukan ahli dari proses validasi pertama dan kedua. Data hasil validasi materi pada tahap ketiga oleh ahli materi dengan nilai skala 100 disajikan pada Tabel 1 berikut ini. 
Tabel 1, Hasil Validasi Materi oleh Ahli

\begin{tabular}{lll}
\hline No. Aspek yang diamati & Presentase & Interpretasi \\
\hline 1. Desain materi isi e-learning & 93,33 & Sangat baik \\
2. Paparan materi & 86,67 & Sangat baik \\
3. Bahasa & 85,00 & Sangat baik \\
\hline Rata-rata & $\mathbf{8 8 , 3 3}$ & Sangat baik \\
\hline
\end{tabular}

Berdasarkan data di atas, hasil validasi materi oleh ahli menunjukkan nilai rata-rata untuk ketiga aspek adalah 88,33. Dengan interpretasi skala Likert, hasil rata-rata tersebut menunjukan bahwa e-learning berbasis CMS Joomla dari segi isi materi Fisika dinilai sangat baik, seperti digambarkan dalam histogram berikut ini.

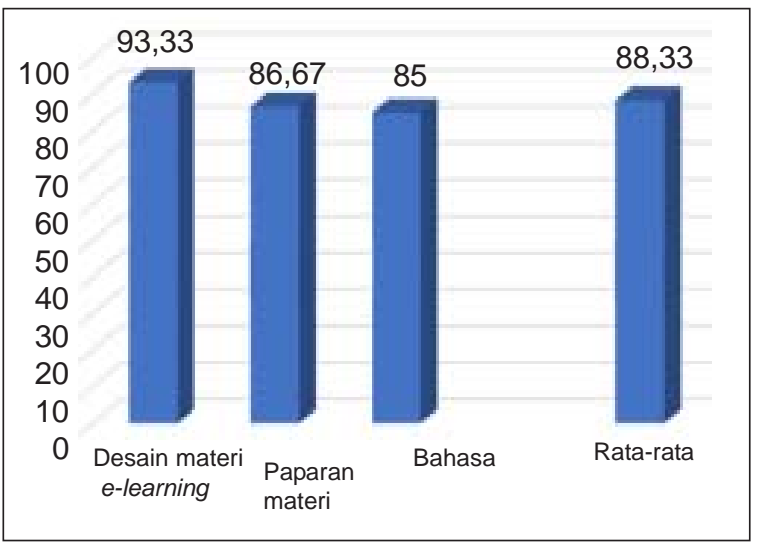

Gambar 10, Histogram Hasil Validasi Materi oleh Ahli

Ahli materi memberikan penilaian bahwa model e-learning telah menampilkan konten Fisika yang sesuai dengan materi dan konsep Fisika yang terkait. Penyajian gambar, video, data, tabel, grafik, dan persamaan matematis dalam model e-learning sangat mendukung bagi peserta didik untuk memahami konsep Fisika yang dipelajari. Multi representasi sains yang disajikan telah menghasilkan model elearning yang kontekstual.

Uji validasi media dilakukan oleh ahli yang merupakan dosen Program Studi Pendidikan Fisika Universitas Negeri Jakarta. Media Elearning diuji kelayakannya menggunakan angket dengan 20 pertanyaan dari tiga aspek, yaitu: (1) desain media e-learning; (2) tampilan media e-learning; dan (3) kualitas media elearning. Proses validasi media dilakukan dua kali. Pada validasi pertama didapat beberapa masukan untuk penyempurnaan media $e-$ learning. Data hasil validasi media tahap kedua disajikan dalam skala 100 pada Tabel 2 berikut ini.

Tabel 2, Hasil Validasi oleh Ahli Media

\begin{tabular}{lll} 
No. Aspek yang diamati & Presentase & Interpretasi \\
\hline 1. Desain media e-learning & 90 & Sangat baik \\
2. Tampilan media e-learning & 88,89 & Sangat baik \\
3. Kualitas media e-learning & 80 & Baik \\
Rata-rata & $\mathbf{8 6 , 3 0}$ & Sangat baik \\
\hline
\end{tabular}

Berdasarkan data di atas, hasil rata-rata validasi ahli media untuk ketiga aspek tersebut adalah 86,30. Dengan interpretasi skala likert, hasil rata-rata tersebut menunjukan bahwa elearning berbasis CMS Joomla dari segi media dinilai sangat baik, seperti digambarkan dalam histogram berikut ini.

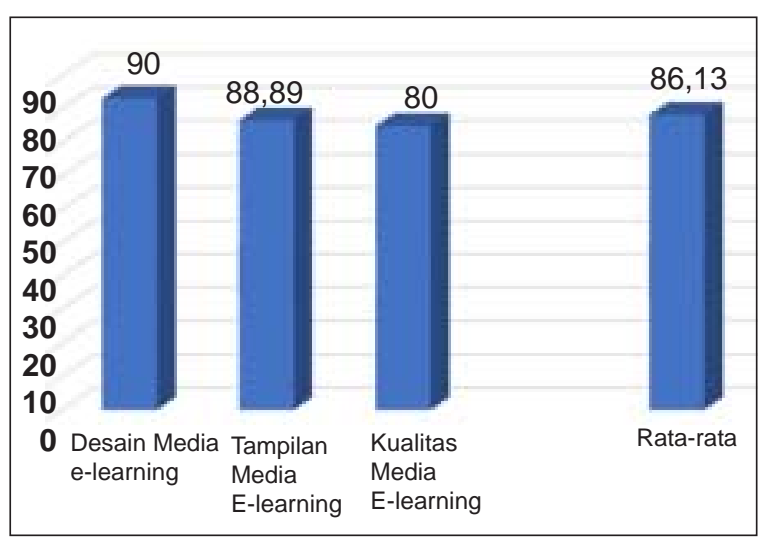

Gambar 11, Histogram Hasil Validasi oleh Ahli Media

Secara media, e-learning yang dikembangkan dengan perangkat CMS Joomla memberikan desain media yang menarik. Desain ini ditengarai akan meningkatkan minat peserta didik dalam memanfaatkan media e-learning dalam membangun konsep Fisika yang harus dipelajarinya. Komponen e-learning yang disajikan secara runtut dan desain tampilan yang menarik merupakan nilai positif yang diberikan oleh ahli media pada model elearning berbasis CMS Joomla ini.

Uji validasi pembelajaran dilakukan oleh ahli yaitu dosen pedagogik program studi pendidikan Fisika. E-learning diuji kelayakannya menggunakan angket dengan 17 pertanyaan dari tiga aspek, yaitu: (1) 
penyajian materi pembelajaran; (2) kegiatan pembelajaran; dan (3) penilaian pembelajaran. Proses validasi pembelajaran dilakukan 3 kali. Pada proses validasi pertama dan kedua didapat beberapa masukan untuk penyempurnaan proses pembelajaran yang kontekstual dan menampilkan multirepresentasi sains. Data hasil validasi pembelajaran oleh ahli pada tahap ketiga disajikan dalam nilai skala 100 pada Tabel 3 berikut.

Tabel 3, Hasil Validasi oleh Ahli Pembelajaran

\begin{tabular}{llll}
\hline No. & Aspek yang diamati & Presentase & Interpretasi \\
\hline 1. Penyajian materi pembelajaran & 90 & Sangat baik \\
2. Kegiatan pembelajaran & 91,42 & Sangat baik \\
3. Penilaian pembelajaran & 95 & Sangat baik \\
& Rata-rata & $\mathbf{9 2 , 1 4}$ & Sangat baik \\
\hline
\end{tabular}

Berdasarkan data di atas, hasil validasi ahli pembelajaran menunjukkan rata-rata untuk ketiga aspek adalah 92,14. Dengan interpretasi skala Likert, hasil rata-rata tersebut menunjukkan bahwa e-learning berbasis CMS Joomla dari segi pembelajaran dinilai sangat baik, seperti digambarkan dalam histogram berikut ini.

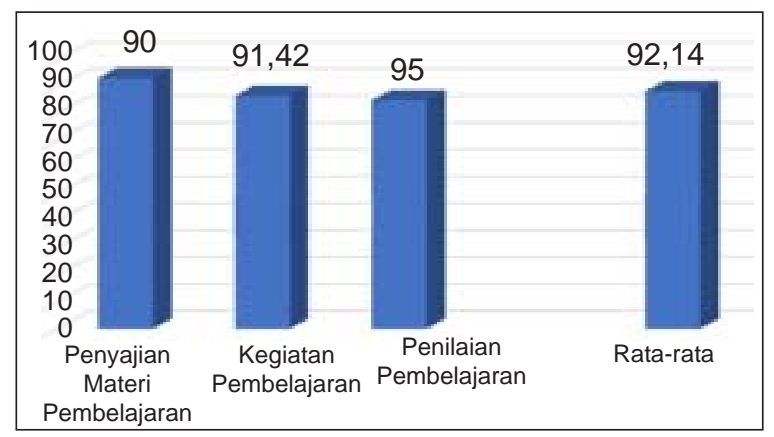

Gambar 12, Histogram Hasil Validasi Pembelajaran oleh Ahli

Uji coba lapangan dilakukan oleh guru Fisika SMA Negeri 30 Jakarta. E-learning diuji kelayakannya menggunakan angket dengan 18 pertanyaan dari tiga aspek. Data hasil uji coba lapangan oleh guru Fisika SMA disajikan dalam nilai skala 100 pada Tabel 4 berikut.

Tabel 4 Hasil Uji Coba Lapangan (Guru)

\begin{tabular}{lll}
\hline No. Aspek yang diamati & Presentase & Interpretasi \\
\hline 1. Cakupan materi & 93,3 & Sangat baik \\
2. Kegiatan pembelajaran & 92 & Sangat baik \\
3. Bahasa & 90 & Sangat baik \\
\hline \multicolumn{1}{c}{ Rata-rata } & $\mathbf{9 1 , 7 8}$ & Sangat baik \\
\hline
\end{tabular}

Berdasarkan data di atas, hasil uji coba lapangan oleh guru Fisika SMA menunjukkan rata-rata untuk ketiga aspek adalah 91,78. Dengan interpretasi skala Likert, hasil ratarata tersebut menunjukan bahwa kelayakan e-learning berbasis CMS Joomla yang akan digunakan oleh peserta didik SMA dinilai sangat baik. Materi sudah disajikan secara kontekstual dengan tampilan multiple representasi sains. Proses pembelajaran yang saintifik sudah sesuai dengan tuntutan kurikulum yang digunakan di SMA. Penilaian perangkat e-learning oleh guru digambarkan dalam histogram berikut ini.

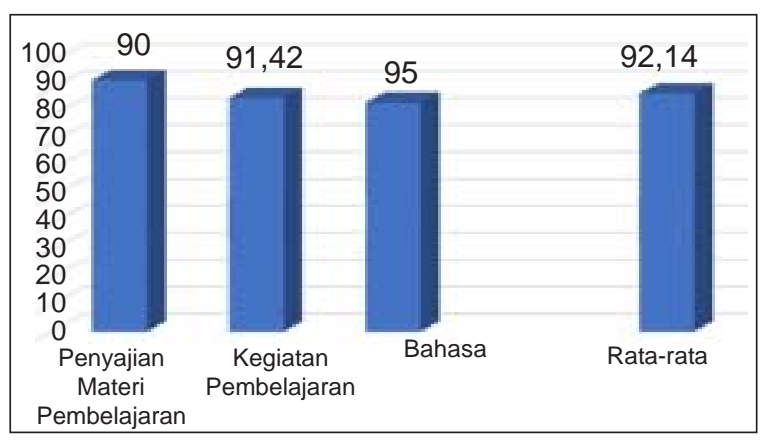

Gambar 13, Histogram Hasil Uji Coba Lapangan (Guru)

Setelah melakukan uji validasi oleh ahli dan uji lapangan oleh guru didapat beberapa saran untuk perbaikan e-learning berbasis Joomla, yaitu: (1) untuk paparan materi masih perlu banyak contoh video dalam kehidupan sehari-hari; dan (2) penulisan simbol diusahakan dapat diberikan kepada siswa sesuai dengan konsep awal saat siswa di SMP untuk menyelaraskan konsep.

Kemudian dilakukan revisi berdasarkan saran-saran yang diberikan. Selanjutnya, dilakukan uji keterbacaan materi Fisika yang dipaparkan secara kontekstual dan multirepresentasi sains oleh peserta didik SMA sebanyak 15 orang. Proses ini dilakukan untuk menyempurnakan produk e-learning berbasis CMS Joomla. Diperoleh beberapa saran perbaikan dari peserta didik. Ada beberapa bagian yang kurang dipahami atau terjadi kesalahtafsiran terhadap konsep yang dipelajari peserta didik. Saran perbaikan tampilan waktu dalam pelaksanaan tes akhir pembelajaran sebaiknya dilakukan dalam hitungan mundur. 
Setelah melakukan perbaikan, dilakukan uji coba skala kecil kepada 20 peserta didik SMA kelas $X$. Proses uji coba dilakukan tiga langkah yaitu pre-test, penggunaan media elearning, dan diakhiri dengan post-test. Peserta didik mengerjakan 20 soal pre-test. Setelah pre-test, peserta didik diberi penjelasan tentang penggunaan perangkat $e$ learning. Peserta didik mempelajari konsep kinematika gerak pada kecepatan dan percepatan tetap selama 3 hari. Setelah belajar menggunakan perangkat e-learning, proses diakhiri dengan post-test. Post-tes dilakukan dengan menggunakan perangkat tes sebanyak 20 soal yang setingkat dengan soal pre-test. Hasil pre-tes mempunyai nilai rata-rata 42,5 dan post-tes mendapat nilai rata-rata 61,75. Hasil tersebut diolah menggunakan uji gain ternormalisasi. Hasil ujicoba penggunaan media oleh peserta didik memberikan nilai gain 0,335. Artinya, penggunaan media e-learning secara mandiri oleh peserta didik memberikan tambahan pengetahuan yang cukup signifikan. Media elearning dapat digunakan sebagai model pembelajaran Fisika.

Setelah menggunakan media e-learning, peserta didik diberikan angket agar mereka memberikan penilaian terhadap tampilan, konten, dan bahasa yang digunakan. Hasil penilaian dalam skala 100 oleh peserta didik disajikan pada Tabel 5 berikut.

Tabel 5, Hasil Uji Coba Lapangan oleh Peserta Didik SMA

\begin{tabular}{lll}
\hline No. Aspek yang diamati & Presentase & Interpretasi \\
\hline 1. Tampilan E-learning & 86,75 & Sangat baik \\
2. Konten E-learning & 81,56 & Sangat baik \\
3. Bahasa & 88 & Sangat baik \\
$\quad$ Rata-rata & $\mathbf{8 5 , 4 4}$ & Sangat baik \\
\hline
\end{tabular}

Hasil uji coba lapangan pada peserta didik SMA menunjukkan bahwa tampilan media elearning sudah sangat baik. Peserta didik sangat tertarik dengan tampilan materi, penempatan dan jenis video yang mendukung pembelajaran, representasi sains yang disajikan sangat mendukung proses pembelajaran serta bahasa yang digunakan sangat mudah dimengerti.
Secara materi, media, pembelajaran, dan kajian oleh pengguna guru dan peserta didik, media e-learning berbasis CMS Joom/a mendapatkan penilaian yang positif. Model $e-$ lerning yang dibangun melalui perangkat $C M S$ Joomla dapat digunakan sebagai model pembelajaran Fisika berbasis web. Kemudahan dalam menampilkan beberapa media, menghasilkan model e-learning yang multi representasi sains. Selain itu, paparan materi dapat dibuat kontekstual sehingga peserta didik dapat belajar secara mandiri. Media e-learning yang menyajikan materi Fisika secara kontekstual, multi representasi, dan ditata secara pedagogik dapat dimanfaatkan sebagai model pembelajaran bagi peserta didik. Tampilan multi representasi memperkaya konten yang dikembangkan terutama untuk program pembelajaran (Srihartini, 2014).

Tampilan model e-learning yang dihasilkan dapat mendukung proses pembelajaran dan pengajaran secara elektronik (Jethro, Grace \& Thomas, 2012). Tampilan secara elektronik akan memudahkan peserta didik memahami konsep yang dipelajari. Video dan animasi yang disajikan memperkaya pemahaman peserta didik akan konsep Fisika yang dipelajarinya. Model e-learning yang multi representatif dan disajikan secara kontekstual telah memenuhi model pembelajaran masa depan seperti yang dinyatakan Goyal dalam artikelnya yang berjudul "E-Learning: Future of Education". Model ini memberikan kebebasan kepada peserta didik untuk melakukan pembelajaran. Konten e-learning sudah disajikan secara interaktif, menarik, dan menghibur (Goyal, 2012).

\section{SIMPULAN DAN SARAN}

Media e-learning yang dikembangkan menggunakan CMS Joomla dinyatakan layak dan dapat digunakan sebagai model pembelajaran Fisika di SMA. Selain itu, media e-learning yang berbasis CMS Joomla ini menunjukkan bahwa tampilannya sudah menarik untuk digunakan, isi materinya sangat membantu peserta didik untuk memahami konsep yang dipelajari, serta bahasa yang digunakan mudah dimengerti dan tidak 
multitafsir. Jadi media e-learning berbasis CMS Joomla yang disajikan secara kontekstual dan multi representasi dapat memudahkan peserta didik memahami konsep Fisika yang dipelajari. Media elearning yang menyajikan materi Fisika secara kontekstual, multi representasi dan ditata secara pedagogik dapat dimanfaatkan sebagai model pembelajaran bagi peserta didik.

\section{PUSTAKA ACUAN}

\section{Buku}

Dick, W., Carey, L., \& Carey, J. O. 2015. The Systematic Design of Instruction. United States of America: Pearson.

Husamah. 2014. Pembelajaran Bauran (Blended Learning): Terampil Memadukan Keunggulan Pembelajaran Face-To-Face, E-Learning Offline-Online dan Mobil Learning. Jakarta: Prestasi Pustaka Publisher.

\section{Jurnal/prosiding/disertasi/tesis/skripsi}

Altun, A., Y. Gulbahar, O. Madran. 2008. Use of A Content Management System for Blended Learning: Perceptions of Pre-Service Teachers, dalam Turkish Online Journal of Distance Education-TOJDE October 2008 ISSN 1302-6488 Volume: 9 Number: 4, pp 138-153.

Bakri, F, D. \& Muliyati. 2017. Pengembangan Perangkat E-Learning untuk Matakuliah Fisika Dasar II Menggunakan LMS CHAMILO, Jakarta: Jurnal Wahana Pendidikan Fisika. Februari 2017 Vol.2 No.1, ISSN: 2338-1027, hal $25-30$

Daru, A. F. 2013. Integrasi CMS dan LMS untuk Membangun Web Berbasis E-learning dengan Single Login, Semarang: Jurnal Transformatika, Univ Negeri Semarang, Vol 11 No 1, Juli 2013, hal 23-31.

Goyal S. 2012. E-Learning: Future of Education, dalam Journal of Education and Learning. Vol.6 Issue 2, hal. 239-242.

Haryono. 2017. Teknologi Pendidikan dan Pembelajaran Abad 21, Banjarmasin: Prosiding Seminar Nasional Teknologi Pendidikan, 15 Juli 2017, hal. 425-436.

Hussein, Reem Razzaq Abdul, Afaf Badie AlKaddo, 2014, E-Learning by Using Content Management System (CMS). Dalam International Journal of Advanced Computer Science and Applications (IJACSA), Volume 5 (10), hak 106 - 111.
Media e-learning berbasis CMS Joomla yang sudah dihasilkan supaya digunakan atau dimanfaatkan pendidik dan/atau peserta didik dalam proses pembelajaran Fisika di SMA khususnya kelas X. Selain itu, media $e$ learning berbasis CMS Joomla perlu diteliti efektivitasnya sebagai model pembelajaran sehingga proses pembelajaran di kelas lebih ditekankan pada pemantapan kompetensi dan karakteristik peserta didik.

Jethro, O.O., A.M. Grace, dan A.K. Thomas.2012. E-Learning and Its Effects on Teaching and Learning in a Global Age, dalam International Journal of Academic Research in Business and Social Sciences, January 2012, Vol 2 Issue 1, hal. 203-210.

Kurniawan, B. P., Bektiarso, S., \& Subiki., 2012. Penerapan Model Pembelajaran Children Learning In Science (Clis) disertai Penilaian Kinerja dalam Pembelajaran Fisika untuk Meningkatkan Aktivitas Belajar dan Hasil Belajar Siswa Kelas VIII-A MTS Nurul Amin Jatiroto, Jember: Jurnal Pembelajaran Fisika Universitas Jember Volume 1, Nomor 3, Desember 2012, ISSN : 2301-9794, hal. 328333.

Pujianto, A., Nurjannah, \& Darmadi, I. W., 2013. Analisis Konsepsi Siswa Pada Konsep Kinematika Gerak Lurus, Palu: Jurnal Pendidikan Fisika Tadulako, Vol 1 No 1 2013, hal. 16-21.

Ninoriya, S., P.M. Chawan, B.B. Meshram. 2011. CMS, LMS and LCMS for e-Learning, dalam International Journal of Computer Science Issues, Vol. 8, Issue 2, March 2011, hal. 644647.

Sari, A. T., Bektiarso, S., \& Yushardi. 2012. Penerapan Model Pembelajaran Generatif dengan Metode Demostrasi dalam Pembelajaran Fisika di SMP, Jember: Jurnal Pembelajaran Fisika Universitas Jember Volume 1, Nomor 3, Desember 2012 ISSN : 2301-9794, hal 145-148.

Srihartini. 2014. Pengembanan Sumber Belajar E-Learning. Surakarta: Jurnal Widya Wacana Vol. 9 Nomor 1 Januari 2014, hal. 67-75.

Wibawa, M. Fandi, 2017, Pengembangan Modul Berbasis E-Learning Dengan Menggunakan CMS Joomla Pada Mata Pelajaran Animasi 2d Kelas XI di SMKN 3 Surabaya. Surabaya: Jurnal IT-Edu, Vol 01 (02) hal 32-37.

Wijaya, E.Y., D.A. Sudjimat, A. Nyoto. 2016. Transformasi Pendidikan Abad 21 sebagai Tuntutan Pengembangan Sumber Daya 
Manusia Di Era Global, Malang: Prosiding Seminar Nasional Pendidikan Matema-tika 2016 Universitas Kanjuruhan Malang, Vol 1 Tahun 2016, hal. 263-278.

\section{Lain-lain}

Gunadi, I. Made, \& Lirva. 2007. Joomla! Website Magic, Dengan Joomla! bikin website semudah memasak Mie Instan. Jasakom, Jakarta. http://www.jasakom. com/penerbitan (diunduh pada 20 November 2017). 